\title{
Climate change impact on vegetation: lessons from an exceptionally hot and dry decade in south-eastern France
}

\author{
Vennetier Michel (1-2)* and Ripert Christian (1) \\ (1) Cemagref, Aix en Provence, CS 40061, \\ 13182 Aix en Provence Cedex 5 France \\ (2) ECCOREV, FR 3098, Aix-Marseille Université, \\ BP 80 F-13545 Aix en Provence cedex France
}

\section{Introduction}

For the $21^{\text {st }}$ century, all climatic models predict in the Mediterranean basin a faster warming than in most other continental areas of the world, associated with a reduction of rainfall during the growth season (Hesselbjerg-Christiansen \& Hewitson, 2007). As warming is likely to be larger in summer, extreme climatic events such the 2003 scorching heat (Ciais et al. 2005; Zaitchik et al. 2006) are prone to be recurrent. Drought being already the main limiting factor for Mediterranean vegetation (Le Houerou, 2005), many species should be at risk with repeated critical water stress during the growth season (Breda et al., 2006).

According to several studies, (Hughes, 2000; Lenoir et al., 2008) the track race between climate change and vegetation is already launched. Many species looking for suitable habitats move towards the poles or upwards in elevation (Walther et al., 2005). However, mean plant dissemination distance is short (Clark et al., 1999). Certain plants may be unable to follow the edges of their potential distribution area, as fast species spread recorded at the end of ice ages (Delacourt \& Delacourt, 1987) are slower than the expected limit shift in the 21st century (Thuiller, 2004). Species shift should be checked by biotic interactions (Preston et al., 2008) and competition. Time lags in plant phonology (Menzel \& Fabian, 1999) could make them more vulnerable to meteorological extreme events (Morin et al., 2007). Altered architectural development and sexual reproduction (Hedhly et al., 2009 and Thabeet et al., 2009), may also hamper their growth and dissemination. Mediterranean small mountains offer to Alpine or middle-European vegetation fragmented but suitable relict niches mainly near their top (figure 1). Inherited from former climate conditions, mixing several biomes in small areas, these niches are biologically very rich (Médail \& Quézel, 1999) with a high level of endemism. But future climate warming raises their potential trailing edge over local summits (Trivedi et al., 2008b). In the absence of functional corridors, current reserve networks may be inadequate to ensure the long-term persistence of these species (Araujo et al., 2004). However, on local scale, site conditions including deep soils and steep northern slopes at the highest elevations may create refuges. Such a precise assessment of favourable 
sites is not easy with existing models. Although many types of models were used to assess the evolution in plant composition with climate change, computing potential distributions, bioclimatic limits or niches (Botkin et al., 2007; Hansen et al., 2001), for individual species (Gaucherel et al., 2008; Heikkinen et al., 2006) or species groups, very few of them tackled local scales (Trivedi et al., 2008b). This is why we recently developed a new bioclimatic model, based on a flora census, taking into account both local and global variables (Table 1) (Vennetier et al., 2008) in order to bridge regional to local scales. One of the possible uses of this model is to assess the potential flora composition turnover with different simulated climate scenarios (Vennetier et al., 2009).

Flora composition is often considered as a good indicator of site conditions, including site and climate parameters (Berges et al., 2006). A hotter and drier climate should lead to a significant flora turnover biased towards heat and drought tolerant plants. However, if the speed of an altitudinal or latitudinal species shift was often assessed in literature, the turnover was rarely documented on local scale. During the decade 1998-2008, south-eastern France experienced an anticipated occurrence of what should be the climate around 2040 according to IPCC B2 or A1B scenarios (Christensen \& Christensen, 2007). It was interesting to assess whether these exceptional conditions were reflected in flora composition.

The aims of this study were (i) to measure plant composition evolution in a permanent plot network between 1998 and 2008, (ii) to compare the observed evolution with the potential turnover computed with our model (iii) to disentangle the relationships between observed changes and local site conditions.

\section{Material and method}

\subsection{Study area and sampling}

The study area is situated in the French Mediterranean area (figure 1; long $4^{\circ} 5^{\prime}-6^{\circ} 2^{\prime}$ E, lat $\left.43^{\circ} 4^{\prime}, 43^{\circ} 5^{\prime} \mathrm{N}\right)$. The climate is characterized by a long summer drought ( $2-4$ months) and mild rainy winters. The mean annual temperature and rainfall range respectively from $15.3^{\circ} \mathrm{C} / 500 \mathrm{~mm}$ on the Southwestern coast to $9.5^{\circ} \mathrm{C} / 1000 \mathrm{~mm}$ on the highest ridges (around $1100 \mathrm{~m}$ ), with an average of $13.2^{\circ} \mathrm{C} / 720 \mathrm{~mm}$. Pinus halepensis Mill. and Quercus ilex L. are the main forest tree species along the coast, at low elevation and on shallow soils, while Quercus pubescens Will. is all the more abundant as elevation, continentality and soil depth increase.

The sampling plan was design to be representative of the span of local and global site conditions, crossing the main ecological gradients: soil quality, topography, orientation, climate, continentality (Table 1). In order to minimize the role of disturbances in vegetation response, we selected only sites with no registered disturbing activity such as logging, grazing, clearing, or prescribed fire over at least the last 30 years. In most of these sites, dominant trees were more than 70 years old. Initially, 325 forest plots $\left(400 \mathrm{~m}^{2}\right.$ each) were surveyed between 1996 and 1998. A thorough description and measure of site conditions was performed, along with a flora census using Braun-Banquet abundance-dominance scale (Braun-banquet 1932). The flora census was done again in 2008 on a representative subsample of 50 plots. 


\subsection{Model bases}

The main output of the model, previously presented by Vennetier et al. (2008), is a bioclimatic index. This index combines two components: the first one is based on variables which can be mapped by GIS from local to regional scale (climate, continentality and orientation); the second one is based on variables which can be precisely observed only on site scale (soil, local topography). In this section, only the bases of the model which are useful for this study are explained. Statistical procedures are described in annex 1.

The model was designed in two steps.

The first step was a correspondence analysis (CA) on plant composition with the 325 plots, keeping 192 species present in at least 3 plots. Figure $2 a$ shows a synthesis of the main CA plane. When displayed as supplementary variables in this plane, all variables relevant in terms of water balance or temperature, and which could be grouped in four main gradients, were linked to axis 1 . All their classes related to unfavourable conditions (low water availability, high temperatures) were found in the left half of the plane and favourable classes in the right half. Considering its dominance (eigenvalue twice the one of second axis), this first axis was retained alone for modelling and considered as a synthetic bioclimatic gradient.

When displayed in the same plane, plant species are sorted along axis 1 in the synthetic gradient. According to their coordinate on this axis, they can be split into five groups of equal number from the left (the most heat and drought tolerant) to the right (water demanding ones) (figure 2.b): super xero-thermophilous (sXT), xero-thermophilous (XT), intermediate (Int), slightly mesophilous (Meso) and mesophilous (Meso+). Plots can be displayed in the main CA map. As their position is only determined by their flora composition (plots are at the barycentre of their plants), we considered their coordinate on axis 1 as a Flora index (Fi), sorting them too along the bioclimatic gradient.

The second step consisted in computing a bioclimatic index (Bi) for each plot. Bi is the estimate of Fi with a Partial Least Square regression model using abiotic explanatory variables describing site conditions. Table 1 presents the height global and six local relevant variables. The model explained $81 \%$ of Fi variance. Thanks to the good fit between $\mathrm{Fi}$ and $\mathrm{Bi}$, and to the key role played by climate variables in the model, the impact of climate change on plant composition can be assessed as described in paragraph 2.3 below.

\begin{tabular}{|c|c|c|c|}
\hline & Coef* & Variable description & $\begin{array}{l}\text { Gradient in fig } \\
2 \mathrm{a}\end{array}$ \\
\hline \multirow{8}{*}{ 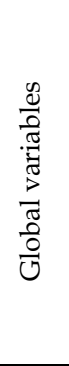 } & -0.183 & $\begin{array}{l}\text { Becker light-climate index (relative received solar energy in } \\
\% \text { of an horizontal reference plane) }\end{array}$ & 2 \\
\hline & -0.153 & Mean annual temperature & 1 \\
\hline & 0.131 & Altitude & 1 \\
\hline & 0.115 & Summer rainfall (cumulated from June to August) & 1 \\
\hline & 0.082 & Annual rainfall excluding summer, or spring rainfall & 1 \\
\hline & 0.169 & \multirow{2}{*}{$\begin{array}{l}\text { Maximum altitude between a site and the coastline in two } \\
\text { directions: the closest coast line and } 247^{\circ}\end{array}$} & 1 \\
\hline & 0.146 & & \\
\hline & 0.106 & Distance to the sea & 1 \\
\hline \multirow{2}{*}{ चू } & -0.136 & $\begin{array}{l}\text { General topography on landscape and slope scale } \\
\text { (5 classes scale) }\end{array}$ & 4 \\
\hline & -0.107 & Topography on local scale (plot size) (5 classes scale) & 4 \\
\hline
\end{tabular}




\begin{tabular}{|l|l|l|l|}
\hline-0.083 & Percentage of parent rock outcrops on the plot & 4 \\
\hline 0.100 & $\begin{array}{l}\text { Water holding capacity of earth }(\mathrm{mm} / \mathrm{cm}) \text { based on soil } \\
\text { texture }\end{array}$ & 3 \\
\hline-0.091 & Percentage of coarse fragments in the soil & 4 \\
\hline 0.119 & Total soil depth & 4 \\
\hline
\end{tabular}

Table 1. variables describing site conditions and used for the model

* Coef. = Partial regression coefficient in the PLS regression model. All theses coefficients are highly significant $(\mathrm{P}<0.001)$. They sort variable by their relative weight in the model.

The initial CA, using the flora census of 1996-98, was computed with the climate of the period 1961-1996.

\subsection{Simulation of climate change impact on plant turnover}

The simulation used the two steps of the model:

First, we considered that an increasing mean annual temperature or decreasing spring or summer rainfall would favour xero-thermophilous species, and stress mesophilous ones. We simulated this impact (Figure 3), changing at plant distribution margins of each plot the composition $(3 b)$ or the abundance-dominance $(3 c)$.

Using these modified plots as supplementary observations in the initial CA, we computed the new coordinates of each plot on axis 1 (Figure 3), which means new and smaller Fi indices (modified plots shifted to the left in the CA plane).

In the second step, we simulated various climate change scenarios, with lessening summer or spring rainfall $(-10$ to $-30 \%)$ and raising temperatures $\left(1\right.$ to $\left.2{ }^{\circ} \mathrm{C}\right)$. We also used in the model the mean climate observed over respectively the last 10, 20 and 30 years (1978-2007). New and smaller Bi indices for each plot were computed.

The good correlation between $\mathrm{Fi}$ and $\mathrm{Bi}$ indices enabled linking their respective shift with the flora and climate change simulations, and therefore assessing the plant composition turnover expected for each climate scenario. We did not consider the future of individual or specific plants, but the global turnover as a percentage of plant composition.

\subsection{Validation with the new flora census}

This census was performed in spring 2008 by the same team using exactly the same protocols. We analysed the flora turnover as the changes in plant presence and abundancedominance, on one hand with all plants separately, and on the second hand considering the five groups of grading heat and drought tolerance designed in figure $2 a$.

\section{Results}

\subsection{Number of plants per plot}

The average number of plants was $25(7-53, \mathrm{SD}=8)$ in the 325 initial plots, and $27(15-48$, $\mathrm{SD}=7.5$ ) in the 50 plots surveyed twice. This average number was unchanged in the last 10 years although its mean absolute variation was 18\% (4 - 5 plants), gains in some plots compensating losses in others. The number of plants per plot increased regularly with plot If $\left(r^{2}=0.22, p<0.05\right)$ ranging from 22 for If lowest fourth to 32 for If highest fourth: as a whole, mesophilous sites were richer than drier sites. However, percentage variations in the number of plants per plot did not depend on If. 


\subsection{Simulation of climate and plant composition changes}

Table 2 sorts the If shift for different simulations of climate change and plant composition change. This relation is given as an average for all plots. For a given number of plants changing at the edge of the distribution margins, the richer the plot and the smaller its span, the less sensible it is to these changes. For example, the change of +2 and -2 plants gave an average shift of 0.181 $(\mathrm{SD}=0.063)$ with maximum / minimum values of respectively 0.503 for a plot with 10 species and a wide distribution and 0.088 for a plot with 50 species and a narrow distribution. As the number of plants affected by climate change may be proportional to their total number, we used percentages of flora composition to express changes, making the results independent of plot specific flora.

A reduction of $20 \%$ of spring or summer rainfall corresponded to a change of 4 to $5 \%$ in flora composition. Each added ${ }^{\circ} \mathrm{C}$ increased by 7 to $8 \%$ flora turnover. The mean climate of the last 10 years led to a potential change of one fourth of plant composition.

For a given plot, the mean shift of If observed with the decrease / increase of one point for the Braun-Blanquet coefficient of a plant was $60 \%$ of the shift obtained with the suppression of this plant or the addition of the closer plant.

\begin{tabular}{|c|c|c|c|}
\hline \multicolumn{2}{|l|}{ Simulations } & \multirow[t]{2}{*}{$\begin{array}{|lc|}\% & \text { of } \\
\text { composition } & \text { flora } \\
\end{array}$} & \multirow[t]{2}{*}{\begin{tabular}{|l|}
$\begin{array}{l}\text { If shift on axis } 1 \\
\text { (mean all plots) }\end{array}$ \\
\end{tabular}} \\
\hline Climate change & Flora change & & \\
\hline \multirow{2}{*}{$-10 \%$ SpR or SumR } & & & -0.030 \\
\hline & (1) -1 or +1 plant & $4 \%$ & -0.050 \\
\hline$-20 \%$ SpR or SumR & & & -0.052 \\
\hline$+1^{\circ} \mathrm{C}^{*}$ & & & -0.074 \\
\hline \multirow[t]{3}{*}{$\begin{array}{llll}+1^{\circ} \mathrm{C} & -10 \% & \mathrm{SpR} & \text { or } \\
\text { SumR } & & & \\
\end{array}$} & & & -0.105 \\
\hline & (2) -1 and +1 plants & $8 \%$ & -0.106 \\
\hline & $\begin{array}{l}\text { Abond-Domin }+1 \text { or }-1 \text { for } 4 \\
\text { plants }\end{array}$ & & -0.111 \\
\hline \multirow[t]{3}{*}{$+2^{\circ} \mathrm{C}^{*}$} & & & -0.143 \\
\hline & $\begin{array}{l}\text { Abond-Domin }+1 \text { or-1 for } 6 \\
\text { plants }\end{array}$ & & -0.154 \\
\hline & (4) -2 and +2 plants & $16 \%$ & -0.181 \\
\hline $\begin{array}{l}+2^{\circ} \mathrm{C}-10 \% \mathrm{SpR} \text { and }- \\
10 \% \text { SumR }\end{array}$ & & & -0.192 \\
\hline $\begin{array}{lll}+2^{\circ} \mathrm{C} & -20 \% \mathrm{Spr} & \text { or } \\
\text { SumR } & & \\
\end{array}$ & & & -0.193 \\
\hline \multirow[t]{2}{*}{$\begin{array}{l}+1.4^{\circ} \mathrm{C}-15 \% \mathrm{SpR} \text { and } \\
-32 \% \mathrm{SumR}\end{array}$} & & & -0.264 \\
\hline & (6) -3 and +3 plants & $24 \%$ & -0.269 \\
\hline
\end{tabular}

Table 2. Fitting flora turnover and climate change impacts on the shift of plot If. The last example of climate change corresponds to the mean climate of the last 10 years (1998-2008) compared to the reference 1961-96.

* Temperature increase is for mean annual temperature.

SumR = Summer rainfall, $S p R=$ spring rainfall. 


\subsection{Comparison with the observed shift in plant composition}

The observed shift did not occur at random but was biased towards axis 1 bioclimatic gradient. Figure 4 shows the spatial evolution of flora sorted by plant groups.

In the sXT group, nearly half of the plants were winners, two times more than losers. Conversely in the Meso+ and Meso groups, half of the plants were losers, respectively five times and two times more than winners. In the intermediate and XT groups, the turnover was balanced, losers and winners being as numerous, which means that disappearing species were replaced by plants of the same group. 30\% percent of the plants remained spatially stable in the two extreme groups, but only 10 to $15 \%$ in other groups. As a whole, mean plant occurrence was unchanged $(+0.1)$, so that disappearing mesophilous plants were replaced by xero-thermophilous ones. But 74 plants lost occurrences for only 55 gaining ground, which means that only a minority of plants took advantage of the new conditions, even within XT groups.

These percentages of spatial turnover may hide very different situations, as a plant was considered as spatially winner or loser whatever the rate of change. This is why the trend on flora composition towards xero-thermophilous species was more precisely assessed with the sums of occurrences and of Braun-Blanquet coefficients within groups (Figure 5).

The sXT and XT groups together won 73 occurrences, corresponding to 1.5 plants per plot. But their sum of Braun-Blanquet coefficients won 122 points, nearly 2.5 points per plot. It means that not only new xero-thermophilous plants appeared in plots but also that some plants of these groups, already present in 1996-98, increased in dominance and cover. Meso+ and Meso plants lost together 68 occurrences and a bit more (86) in the sum of Braun-Blanquet coefficients, which means that, for these two groups, losses in cover percentage were mainly due to losses in occurrence. Globally the occurrence turnover between xero-thermophyllous and mesophilous plants reached 3 plants, equivalent to $11.5 \%$ in 10 years. Variations in the sum of Braun-Blanquet coefficients which are not explained by occurrence variations must be taken into account. When their equivalent in occurrences was added ( 0.6 occurrence for 1 points of coefficients), the total observed turnover excluding the intermediate group was close to $15 \%$.

This turnover between plant groups was not similar whatever the site. Figure 6 shows that a biased turnover occurred mainly in mesophilous and intermediate sites, very dry and hot sites remaining more or less stable.

\subsection{Mapping $\mathrm{Bi}$ index on various scales}

Bi index computed with global variables was mapped with a GIS software after being split into nine classes (figure 7.a). Each class included 1/9 of Bi total variation interval after exclusion of the $5 \%$ extreme values $(2.5 \%$ at each end). These extreme values were merged with the first and last classes respectively. Range limits of various species match some of these classes. For example the darkest green (class 9) corresponds to the observed niche of Scots pine and related alpine and meso-European relict species, and excludes Pinus halepensis because of deep frost in winter. On average soil conditions and with a neutral topography, class 3 (orange) is the extreme limit of Quercus pubescens. 


\section{Discussion}

\subsection{Validating and quantifying vegetation turnover}

A 5 to $10 \%$ change in plant composition in the same plot between two following censuses, or with different survey methods, is common without any environmental change (Archaux et al., 2006; 2007). But in such a case this change is not related to a specific gradient, as plants within a given group replace each other. In this study, the most mesophilous and xerothermophilous plants (Meso+ and sXT groups) were more concerned, respectively loosing and gaining more than intermediate ones. Meso and XT groups also showed a significantly unbalanced turnover.

The real turnover did not concern only the species at the very limit of species distribution for each plot. More distributed variations along the gradient give a lower If shift on axis one, but the same trend as far as species appear and disappear symmetrically. It may explain why the observed turnover was weaker than the simulated one. Although observed patterns of flora turnover were more complex than the simulated ones, they validate the method used for the simulation.

The observed trend is clearly biased towards heat and drought resistant plants. It is opposed to what is expected in aging forest structures. Indeed, in Southern Europe the Mediterranean ecosystems were transformed by several thousand years of disturbances and development (Blondel and Aronson, 1999). The natural evolution of the unmanaged stands of this study, most of them adult but far from senescence, should be a maturation process leading to an increasing dominance of mesophilous and shade tolerant plants and the reduction of light demanding, generally xero-thermophilous species, inherited from past land uses (Tatoni and Roche, 1994). Probably, the adverse climate conditions in the last decade also contributed indirectly to a hotter and drier microclimate in the undergrowth, limiting canopy density though tree mortality (Allen et al., 2009), low branching rates and reduced leaf area (Thabeet et al., 2009).

The potential turnover (25\%) simulated on plot scale in this study with the climate expected in the middle of the 21st century hold with previous studies on larger scales: Bakkenes et al (2002) showed that $32 \%$ of the European plant species that are present in a grid cell of a few square kilometres in 1990 should disappear from that cell before 2050. High rates of potential extinction among endemic species (average 11\%, up to $43 \%$ ) were forecasted by Malcolm et al. (2006) for the whole Mediterranean basin and other biodiversity hotspots in the world by 2100 .

\subsection{Flora resistance on landscape and local scales}

Plant composition turnover observed in the last decade was significant but not as considerable as simulated by the model. A resistance to climate variations was observed, which may be partly explained by landscape structure. Bi index mapped at any scale is laid out like a patchwork of fragmented bioclimatic classes. When topography and soil are added on local scale, six among the nine classes represented on regional scales with medium site conditions can be found on a single square kilometre of hilly landscape with steep slopes and only one or two hundred meters of difference in elevation. Thanks to that fine grain mosaic, xero-thermophilous plants are scattered everywhere even at high elevation, taking advantage of steep south-facing slopes, shallow and rocky soils. Most of the time, some of them simply remain from degraded ecosystems inherited form former land uses 
and fires. They are ready to sprawl from these positions in presently cold and wet areas when mesophilous species become less competitive because of climate change.

Mesophilous species are supposed survive, in dry and hot areas, in scattered niches combining cool expositions, deep soils and favourable topography. Even when killed by extreme climate events, they may come back by seed dispersal from refuges and long lifespan soil seed-banks (Zobel et al., 2007). However, such a hypothesis is not fully supported by our results. The best soil and topographic conditions proved to be no longer sufficient to compensate the climatic water stress in recent years, leading to the extensive dieback of mesophilous species in good sites. As an example among forest trees and representatives of middle-European relict species, Pinus silvestris L., although limited to the highest elevations and north slopes, paid an heavy tall to 2003 scorching heat and following drought (Thabeet et al., 2009). In the future, the increase in water stress should lead this compensation limit to shift left along axis one, and the turnover to start even in the driest and hottest sites of the study area.

\subsection{Management issues}

Several reserves try to protect Alpine or middle-European flora in Mediterranean mountains. But protected areas are generally fragmented and scattered in developed lands. Corridors are lacking to allow species to move from one to another. This is why it would be necessary to include public and private multi-use lands in conservation practices (Heller \& Zavaleta 2009) and to look for the parts of these human-dominated landscapes that should be suitable for forest species. Bioclimatic maps like figure 7, if regularly updated, could help designing such strategies.

However, many of the small isolated areas of relict vegetation should be kicked out by the top. According to Trivedi et al. (2008a) 70 to $80 \%$ of plant species in similar low mountain conditions should loose most of their potential niche in the next decades, as shown in figure 7.b for Pinus silvestris and associated flora. Moreover, large scale approaches may underestimate this potential climate-based disappearance by far. Extreme weather events may cause larger gaps in already scattered populations (Opdam and Wascher, 2004) and drive them below the critical level of metapopulation persistence. So that ex-situ conservation of endemic and rare species or genetic resources should be urgently implemented. For example, Pinus silvestris in Provence at low elevation proved to be far more resistant to drought than most other origins of this species. This resource could be useful in the future at higher latitudes, and for genetic improvement programs. But most of the concerned stands were killed between 2003 and 2007 and the last ones should soon be lost.

\section{Conclusion}

Combined with exceptionally high temperatures, repeated droughts between 1998 and 2008 severely impacted vegetation in south-eastern France. This unexpected experience allowed assessing, three decades sooner, the consequences of the climate forecasted as normal in the future.

We showed that a rapid turnover occurred in ten years on site scale. It was surprisingly faster in the most favourable sites, were mesophilous species could not survive. It may concern all the study area in the future. Accordingly, the simulations with a bioclimatic 
model forecasted even more extensive changes with the climate of the last decade. Whatever the quality of models, the long term follow-up of permanent plots is irreplaceable to understand and measure the impact of climate change.

As climate change may accelerate in the future, conservation policies for rare and endangered species, and more generally conservation policies based on fixed reserve networks, should be reconsidered. It is particularly relevant in low mountains were the trailing edge of ecological niches for these species should soon reach the highest ridges.

Landscape structure at a scale fitting with a detailed assessment of topographic and soil variables allows an operational assessment of the change in plant composition and the shift in plant future distribution. Taking into account seed dissemination distances may improve such an assessment, as the scales are of the same order. Many parameters including the real species migration capacity, population dynamics, biotic interactions and community ecology should be included in models (Brooker et al., 2007; Guisan \& Thuiller, 2005) to improve the spatial assessment of plant migration in landscapes.

Therefore, such assessments on an operational scale should be multiplied in the main ecosystems and regions, so that large scale approaches could be corrected and better interpreted. Small scales approaches, tailored to specific needs, also enhance local knowledge and encourage dissemination and decision making at operational forest management level. Ecological as well as economical issues are at stake.

\section{Acknowledgements}

The initial flora census (1996-98) and model design was funded by the French Ministry for Agriculture and Fisheries. The second census was funded by the French National Research Agency (DROUGHT+ project, $N^{\circ}$ ANR-06-VULN-003-04). Several students and technicians contributed to field work particularly Jean Stéphane, Estève Roland, Chandioux Olivier and Martin Willy.

\section{References}

Allen, C.D., Macalady, A.K., Chenchouni, H., Bachelet, D., Mcdowell, N., Vennetier, M., Kitzberger, T., Rigling, A., Breshears, D.D., Hogg, E.H., Gonzalez, P., Fensham, R., Zhang, Z., Castro, J., Demidova, N., Lim, J.-H., Allard, G., Running, S.W., Semerci, A., Cobb, N., 2009. A Global Overview of Drought and Heat-Induced Tree Mortality Reveals Emerging Climate Change Risks for Forests, Forest Ecology and Management 259 (4) 660-684

Amato, S., Vinzi, V.E., 2003. Bootstrap-based $\mathrm{Q}^{2} \mathrm{kh}$ for the selection of components and variables in PLS regression, Chemometrics and intelligent Laboratory Systems, (68): 5-16.

Araujo, M.B., Cabeza, M., Thuiller, W., Hannah, L., Williams, P.H., 2004. Would climate change drive species out of reserves? An assessment of existing reserve-selection methods, Global Change Biology, (10) 9: 1618-1626.

Archaux, F., Berges, L., Chevalier, R., 2007. Are plant censuses carried out on small quadrats more reliable than on larger ones?, Plant Ecology, 188: 179-190. 
Archaux, F., Gosselin, F., Berges, L., Chevalier, R., 2006. Effects of sampling time, species richness and observer on the exhaustiveness of plant censuses, Journal of Vegetation Science, (17): 299-306.

Bakkenes M. ; Alkemade J.R.M. ; Ihle F. ; Leemans R. ; Latour J.B. (2002) Assessing effects of forecasted climate change on the diversity and distribution of European higher plants for 2050. Global Change Biology, vol. 8, n 4, p. 390-407.

Berges, L., Gegout, J.C., Franc, A., 2006. Can understory vegetation accurately predict site index? A comparative study using floristic and abiotic indices in sessile oak (Quercus petraea Liebl.) stands in northern France, Annals of Forest Science, (63) 1: 31-42.

Blondel, J., Aronson, J., 1999. Biology and wildlife of the Mediterranean region, Oxford University Press, Oxford.

Botkin, D.B., Saxe, H., Araujo, M.B., Betts, R., Bradshaw, R.H.W., Cedhagen, T., Chesson, P., Dawson, T.P., Etterson, J.R., Faith, D.P., Ferrier, S., Guisan, A., Hansen, A.S., Hilbert, D.W., Loehle, C., Margules, C., New, M., Sobel, M.J., Stockwell, D.R.B., 2007. Forecasting the effects of global warming on biodiversity, Biosciences, (57) 3: 227-236.

Braun-Blanquet J. (1932) Plant sociology. The study of plant communities. McGraw-Hill, NewYork.

Breda, N., Huc, R., Granier, A., Dreyer, E., 2006. Temperate forest trees and stands under severe drought: a review of ecophysiological responses, adaptation processes and long-term consequences, Annals of Forest Science, (63) 6: 625-644.

Brooker, R.W., Travis, J.M.J., Clark, E.J., Dytham, C., 2007. Modelling species' range shifts in a changing climate: The impacts of biotic interactions, dispersal distance and the rate of climate change, Journal of Theoretical Biology, (245) 1: 59-65.

Christensen J H and Christensen O H 2007 A summary of the PRUDENCE model projections of changes in European climate by the end of this century, Climate Change 81: 7-30

Ciais, P., Reichstein, M., Viovy, N., Granier, A., Ogee, J., Allard, V., Aubinet, M., Buchmann, N., Bernhofer, C., Carrara, A., Chevallier, F., De Noblet, N., Friend, A.D., Friedlingstein, P., Grunwald, T., Heinesch, B., Keronen, P., Knohl, A., Krinner, G., Loustau, D., Manca, G., Matteucci, G., Miglietta, F., Ourcival, J.M., Papale, D., Pilegaard, K., Rambal, S., Seufert, G., Soussana, J.F., Sanz, M.J., Schulze, E.D., Vesala, T., Valentini, R., 2005. Europe-wide reduction in primary productivity caused by the heat and drought in 2003, Nature, (437) 7058: 529-533.

Clark J.S. ; Silman M. ; Kern R. ; Macklin E. ; Hillerislambers J. (1999) Seed dispersal near and far: Patterns across temperate and tropical forests. Ecology vol. 80, n 5, p. 14751494.

Delacourt, P., Delacourt, H., 1987. Long-term Forest Dynamics of the Temperate Zone. Springer, New York.

Emberger, L., 1930. La végétation de la région méditerranéenne : essai d'une classification des groupements végétaux, Revue Générale de Botanique, 42: 641-662, 705-721.

Escofier, B., Pages, J., 1994. Multiple Factor analysis, Computational statistics and data analysis, 18: 121-140.

Gaucherel, C., Guiot, J., Misson, L., 2008. Changes of the potential distribution area of French Mediterranean forests under global warming, Biogeoscience, (5) 6: 1493-1504. 
Good, P., 1994. Permutation tests, Springer-Verlag, New-York.

Guiot, J., 1991. Methods and programs of statistics for palaeoclimatology and palaeoecology. In: Quantification des changements climatiques. Méthodes et Programmes, Monographie 1. Marseille: INSU, Paris, 1991, pp. 258.

Guisan, A., Thuiller, W., 2005. Predicting species distribution: offering more than simple habitat models, Ecology Letters, (8) 9: 993-1009.

Hansen, A.J., Neilson, R.R., Dale, V.H., Flather, C.H., Iverson, L.R., Currie, D.J., Shafer, S., Cook, R., Bartlein, P.J., 2001. Global change in forests: Responses of species, communities, and biomes, Bioscience, (51) 9: 765-779.

Hedhly, A., Hormaza, J.I., Herrero, M., 2009. Global warming and sexual plant reproduction, Trends in Plant Science, (14) 1:30-36.

Heikkinen, R.K., Luoto, M., Araujo, M.B., Virkkala, R., Thuiller, W., Sykes, M.T., 2006. Methods and uncertainties in bioclimatic envelope modelling under climate change, Progress in Physical Geography, (30) 6: 751-777.

Heller, N.E., Zavaleta, E.S., 2009. Biodiversity management in the face of climate change: A review of 22 years of recommendations, Biological Conservation, (142) 1: 14-32.

Hesselbjerg-Christiansen, J., Hewitson, B., 2007. Regional Climate Projection. In: IPCC (2007) Climate Change 2007: The Physical Science Basis. Contribution of Working Group I to the Fourth Assessment Report of the Intergovernmental Panel on Climate Change. Solomon, S., D. Qin, M. Manning, Z. Chen, M. Marquis, K.B. Averyt, M. Tignor and H.L. Miller (eds)., Cambridge University Press, Cambridge, United Kingdom and New York, NY, USA. chap 11, pp 847-940.

Hughes, L., 2000. Biological consequences of global warming: is the signal already apparent?, Trends in Ecology and Evolution, (15) 2: 56-61.

Le Houerou, H.N., 2005. The Isoclimatic Mediterranean Biomes: Bioclimatology, Diversity and Phytogeography. Vol. 1 \& 2, Copymania Publication, Montpellier.

Lenoir, J., Gegout, J.C., Marquet, P.A., De Ruffray, P., Brisse, H., 2008. A significant upward shift in plant species optimum elevation during the 20th century, Science, (320) 5884: 1768-1771.

Malcolm J.R. ; Liu C.R. ; Neilson R.P. ; Hansen L. ; Hannah L. (2006) Global warming and extinctions of endemic species from biodiversity hotspots. Conservation Biology, vol. 20, n², p. 538-548.

Médail, F., Quézel, P., 1999. Biodiversity Hotspots in the Mediterranean Basin: Setting Global Conservation Priorities, Conservation Biology, (13) (6): 1510 -1513.

Menzel, A., Fabian, P., 1999. Growing season extended in Europe, Nature, (397) 6721: 659659.

Morin, X., Ameglio, T., Ahas, R., Kurz-Besson, C., Lanta, V., Lebourgeois, F., Miglietta, F., Chuine, I., 2007. Variation in cold hardiness and carbohydrate concentration from dormancy induction to bud burst among provenances of three European oak species, Tree Physiology (27) 6: 817-25.

Opdam, P., Wascher, D., 2004. Climate change meets habitat fragmentation: linking landscape and biogeographical scale levels in research and conservation, Biological Conservation, (117) 3: 285-297.

Preston, K., Rotenberry, J.T., Redak, R.A., Allen, M.F., 2008. Habitat shifts of endangered species under altered climate conditions: importance of biotic interactions, Global Change Biology, (14) 11: 2501-2515. 
R_Development_Core_Team, 2004. R: A language and environment for statistical computing. R Foundation for Statistical Computing, R Foundation for Statistical Computing.

Tatoni, T., Roche, P., 1994. Comparison of Old-Field and Forest Revegetation Dynamics in Provence, Journal of Vegetation Science, (5) 3: 295-302.

Thabeet, A., Vennetier, M., Gadbin-Henry, C., Denelle, N., Roux, M., Caraglio, Y., Vila, B., 2009. Response of Pinus sylvestris L. to recent climate change in the French Mediterranean region, Trees Structure and Functions, (28) 4: 843-853.

Thioulouse, J., Chessel, D., Doledec, S., Olivier, J.M., 1997. ADE-4: a multivariate analysis and graphical display software, Stat. Comput., 7: 75-83.

Thuiller W. (2004) Patterns and uncertainties of species' range shifts under climate change. Global Change Biology, vol. 10, n² 12, p. 2020-2027.

Trivedi, M.R., Berry, P.M., Morecroft, M.D., Dawson, T.P., 2008a. Spatial scale affects bioclimate model projections of climate change impacts on mountain plants, Global Change Biology, (14) 5: 1089-1103.

Trivedi, M.R., Morecroft, M.D., Berry, P.M., Dawson, T.P., 2008b. Potential effects of climate change on plant communities in three montane nature reserves in Scotland, UK, Biological Conservation, (141) 6: 1665-1675.

Vennetier, M., Ripert, C., Maillé, E., Blanc, L., Torre, F., Roche, P., Tatoni, T., Brun, J.-J., 2008. A new bioclimatic model calibrated with flora for Mediterranean forested areas, Annals Forest Science, (65) 711.

Vennetier M., Christian R. 2009. Forest flora turnover with climate change in the Mediterranean region: A case study in Southeastern France. Forest Ecology and Management 258S: 56-63

Walther, G.R., Beissner, S., Burga, C.A., 2005. Trends in the upward shift of alpine plants, Journal of Vegetation Science, (16) 5: 541-548.

Zaitchik B.F. ; Macalady A.K. ; Bonneau L.R. ; Smith R.B. (2006) Europe's 2003 heat wave: A satellite view of impacts and land-atmosphere feedbacks. International Journal of Climatology, vol. 26, nº 6, p. 743-769.

Zobel, M., Kalamees, R., Püssa, K., Roosaluste, E., Moora, M., 2007. Soil seed bank and vegetation in mixed coniferous forest stands with different disturbance regimes, Forest Ecology and Management, (250) 1-2: 71-76.

\section{Annex 1: statistical procedures}

We used a classical unweighted CA analysis with Braun-Blanquet coefficients to obtain the Flora index as the coordinates of plots on the first CA axis. We checked the robustness of the CA axes towards potential inaccuracies of floristic censuses due to time or spatial strategies or the observer (Archaux et al., 2007; Archaux et al., 2006) and towards analyses options. This verification was performed with a Multiple Factorial Analysis (MFA) (Escofier and Pages, 1994) testing the stability of CA axes and plots coordinates: on one hand by increasing the number of plots where a plant must be present to be taken into account from 3 to 30 , on the other hand comparing presence/absence and Braun-Blanquet coefficients in the analysis. 
CA axes 1 to 3 and plots coordinates proved to be particularly stable ( $\mathrm{r}^{2}$ of plot rank on axis $1>0.98$ ) whatever the code used (BB coefficients or presence/absence) and up to a limit of 25 occurrences for plant selection.

Some variables seemed to have non-linear relationship with the Flora index (Fi). To optimize the PLS model, we first checked the relation pattern of all relevant variables with Fi using neural networks and transformed some of them (log, sigmoidal or polynomial). Neural networks where used combining variables 6 by 6 . Each neural network was optimized with a 200 replications bootstrap, each replication including $10^{\wedge} 4$ calibration steps. After the optimization of the neural network, the response of each variable was plotted on its whole variation interval, the other variables being maintained at their mean value if they were not correlated with the tested one, or maintained successively to their first, second and third quartile for those which were correlated.

In the last case, the 3 responses where combined in a sliding weighted mean to obtain the global response. We only transformed a variable according to non-linear relation showed by neural networks when this relation was stable throughout these many tests and enhanced as well (i) the weight of the variable in the neural network optimization and (ii) its partial correlation coefficient or the total explained variance in the PLS regression.

For the choice of relevant variables in the model, we used an ascending and descending stepwise PLS regression validated at each step by a permutation test on PLS components and a cross-validation for concerned variables. All variables in the final version of the model were highly significant on the first two PLS components $(p<0.001)$. The number of significant components for PLS regression was chosen with a 10,000 replications permutation test on observations (Good, 1994), keeping components which percentage of explained variance was not passed by more than $5 \%$ of the permutations. With significant components, variables were sorted through a 1,000 resampling cross-validation test (Amato and Vinzi, 2003); only variables which confidence interval (95\%) for the partial correlation coefficient excluded 0 were used.

We used ADE4 software (Thioulouse et al., 1997) for CA and related operations (introducing supplementary observations and variables), for MFA and PLS permutation tests, Statgraphics ${ }^{\circledR}$ software for stepwise PLS regression, $R$ software (R_Development_Core_Team, 2004) for the cross-validation of PLS variables, and PPPhalos software (Guiot, 1991) for neural networks. 


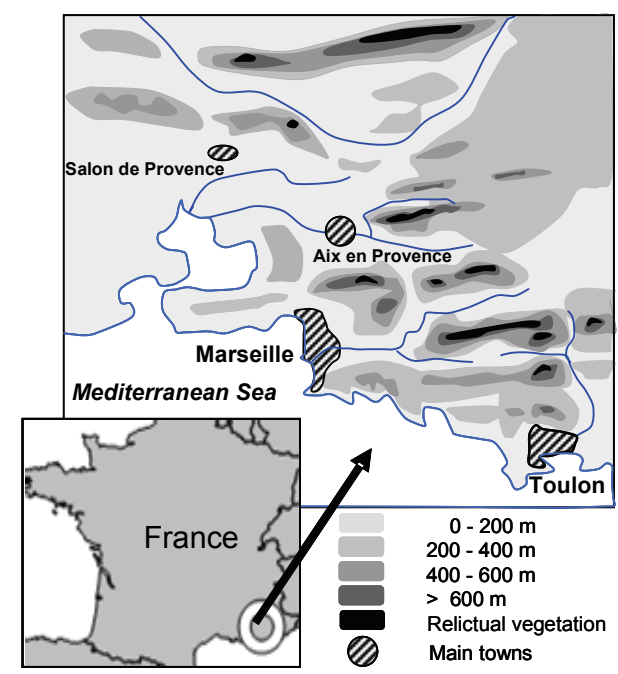

Fig. 1. study area. Alpine and middle-European relict flora remains on steep north slopes near the top of the highest ridges.
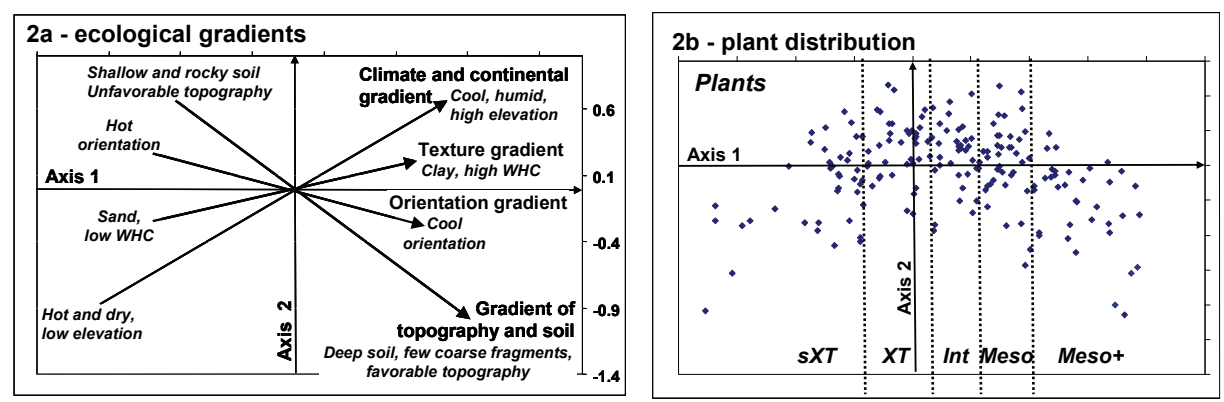

Fig. 2. CA main plane

* fig 2a: synthetic representation of four main ecological gradients related to water balance in the study area, interpreted from the distribution of all variables (see table 1) in CA plane: (1) climate and continentality, (2) orientation, (3) soil texture (water holding capacity), (4) topography and soil quality. These gradients were calculated with a linear regression on the coordinates of the classes of concerned variables in the plane. Axis 1 appeared as the synthesis of these 4 gradients, related to water availability and temperature, integrating local and global scales.

* fig 2b: flora distribution in CA plane. Plant species were split into 5 groups (same number of species in each) according to their coordinate on axis 1 . 


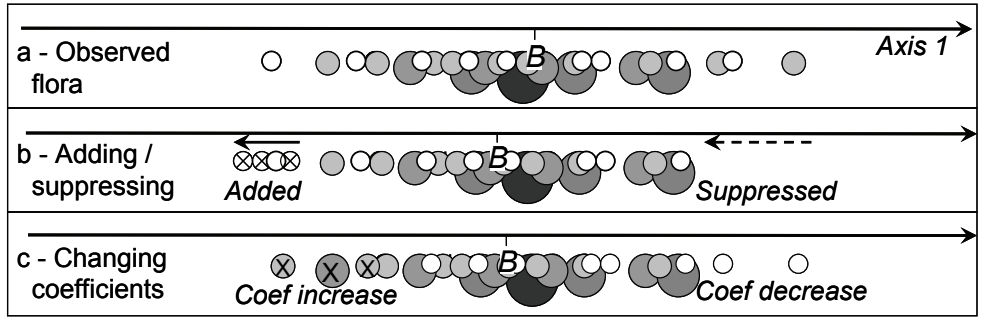

Fig. 3. Simulated flora variations with climate change. Each ring represents one plant species, all the more large and dark as its Braun-Blanquet coefficient is high. $\mathrm{B}=$ barycentre of plant distribution on axis one for the plot = plot Fi.

3a - Observed flora.

$3 \mathrm{~b}$ - One to 3 plants are respectively added / suppressed at the lower / upper margin of the distribution. Added plants are those with the closest coordinates to the last observed species.

$3 c$ - Braun-blanquet coefficients are respectively raised / reduced for one to 3 plants at the lower / upper margin of the distribution. When a plant initially has the smaller coefficient, reducing it amounts to suppressing this plant.

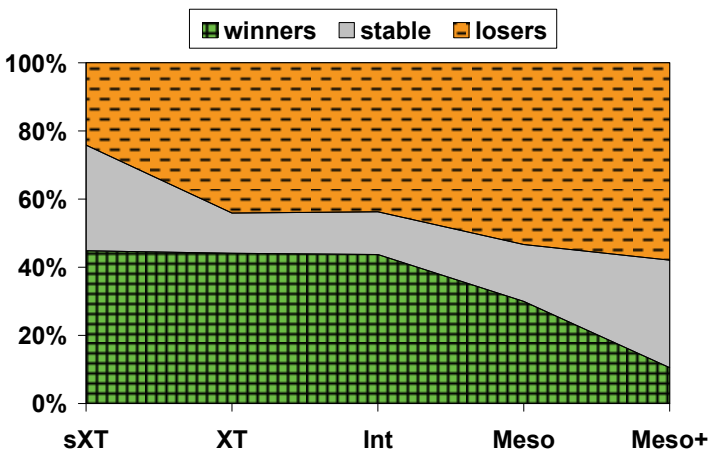

Fig. 4. Variation, between 1996-98 and 2008, of the occurrence of plants according to their tolerance to water stress and heat, as a percentage of the number of plants per group. Winners / losers means plant species respectively present in more / less plots in 2008 than in 1996-98.

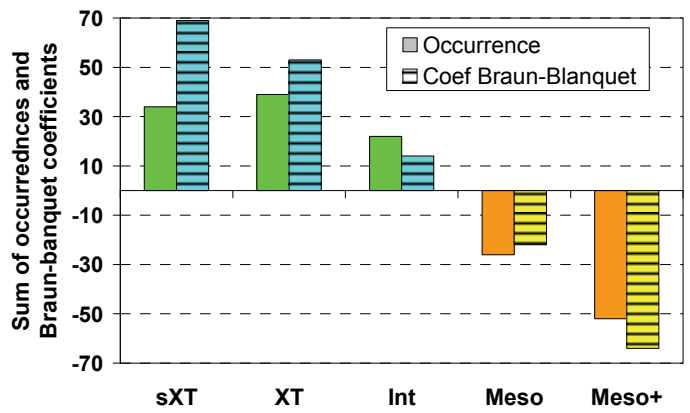

Fig. 1. variations between 1996-98 and 2008 of the sums of occurrences and Braun-Blanquet coefficients per group in the 50 plots revisited in 2008. One occurrence $=$ one species in one plot. 


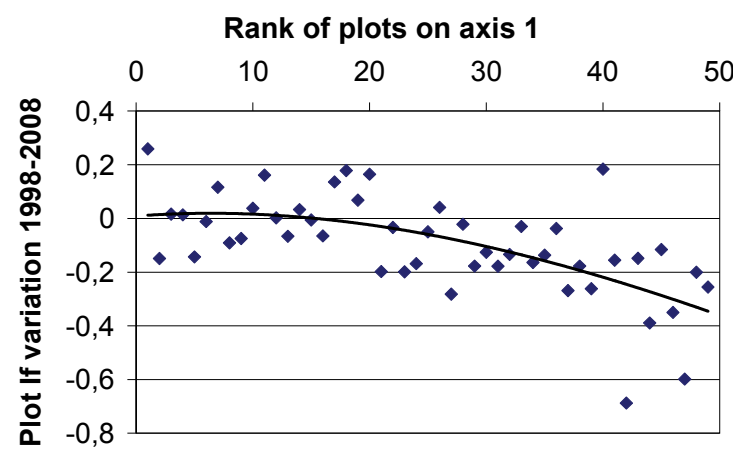

Fig. 6. If variation for the 50 plots resurveyed in 2008 according to their initial position on axis 1 .
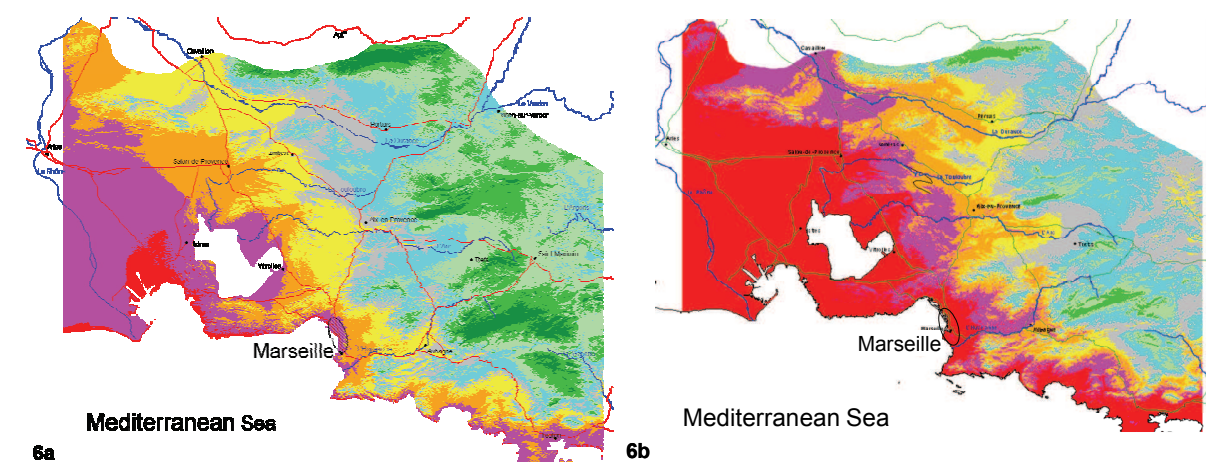

\begin{tabular}{|l|l|l|l|l|l|l|l|l|l|}
\hline Colour & & & & & & & & & \\
\hline Bi class & $\mathbf{1}$ & $\mathbf{2}$ & $\mathbf{3}$ & $\mathbf{4}$ & $\mathbf{5}$ & $\mathbf{6}$ & $\mathbf{7}$ & $\mathbf{8}$ & $\mathbf{9}$ \\
\hline
\end{tabular}

Fig. 7. Bioclimatic index (Bi) computed with global variables and mapped on regional scale with ArcGIS® software in 9 classes of equal Bi index span. The darkest green (class 9) corresponds to the potential niche of Scots pine and related alpine and meso-European relict species. The three shades of green together draw the area of the supra-Mediterranean bioclimate, the blue to pink intermediate colors the meso-Mediterranean and the red the thermo-Mediterranean bioclimate (Emberger, 1930).

7a: Map with 1961-96 mean climate.

7b: Map with 2050 climate (IPCC, B2 Scenario). Relict vegetation has no potential niche left in the study area. Q. pubescens should move away far from the coast, and the growth of $P$. halepensis been slower in most of the study area.

\section{Abstract}

The ongoing climate change causes a rapid shift of plant distribution at various scales. In South-eastern France from 1998 to 2008, Mediterranean forests experienced an exceptionally hot and dry episode following a regular but more limited warming since the 70 's. Flora 
turnover for this period was both simulated at local scale with a bioclimatic model and measured in permanent plots with two censuses. Model prediction for this turnover with the mean climate of the last 10 years was $25 \%$. A $14 \%$ turnover was observed in the permanent plots between the two censuses, fully biased against water demanding species. Changes were all the more fast than sites were favorable (high altitude, cool orientation, deep soils, favorable topography), and were not significant in the driest and hottest sites. This proves that the main changes occurred when the compensation of climatic water deficits by local site favorable conditions was no longer sufficient to allow mesophilous species to survive. Such a threshold should shift towards hottest and driest situations with the future climate. On the landscape scale, various strategies allow a partial plant composition resistance. However, current reserve networks may be inadequate to ensure long-term species persistence. With the measured flora shift, most of the rare species protected in these reserves would potentially disappear from the study area soon in the second half of the $21^{\text {st }}$ century.

\section{Keywords:}

Climate change; flora turnover; resurvey; bioclimatic model; ecological niche; reserves 


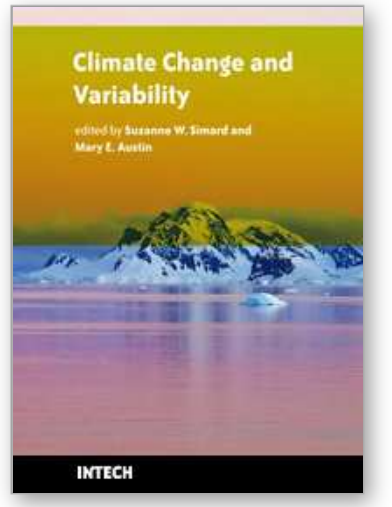

\author{
Climate Change and Variability \\ Edited by Suzanne Simard
}

ISBN 978-953-307-144-2

Hard cover, 486 pages

Publisher Sciyo

Published online 17, August, 2010

Published in print edition August, 2010

Climate change is emerging as one of the most important issues of our time, with the potential to cause profound cascading effects on ecosystems and society. However, these effects are poorly understood and our projections for climate change trends and effects have thus far proven to be inaccurate. In this collection of 24 chapters, we present a cross-section of some of the most challenging issues related to oceans, lakes, forests, and agricultural systems under a changing climate. The authors present evidence for changes and variability in climatic and atmospheric conditions, investigate some the impacts that climate change is having on the Earth's ecological and social systems, and provide novel ideas, advances and applications for mitigation and adaptation of our socio-ecological systems to climate change. Difficult questions are asked. What have been some of the impacts of climate change on our natural and managed ecosystems? How do we manage for resilient socio-ecological systems? How do we predict the future? What are relevant climatic change and management scenarios? How can we shape management regimes to increase our adaptive capacity to climate change? These themes are visited across broad spatial and temporal scales, touch on important and relevant ecological patterns and processes, and represent broad geographic regions, from the tropics, to temperate and boreal regions, to the Arctic.

\title{
How to reference
}

In order to correctly reference this scholarly work, feel free to copy and paste the following:

Michel Vennetier (2010). Climate Change Impact on Vegetation: Lessons from an Exceptionally Hot and Dry Decade in South-Eastern France, Climate Change and Variability, Suzanne Simard (Ed.), ISBN: 978-953-307144-2, InTech, Available from: http://www.intechopen.com/books/climate-change-and-variability/climatechange-impact-on-vegetation-lessons-from-an-exceptionally-hot-and-dry-decade-in-south-easter

\section{INTECH}

open science | open minds

\author{
InTech Europe \\ University Campus STeP Ri \\ Slavka Krautzeka 83/A \\ 51000 Rijeka, Croatia \\ Phone: +385 (51) 770447 \\ Fax: +385 (51) 686166 \\ www.intechopen.com
}

\author{
InTech China \\ Unit 405, Office Block, Hotel Equatorial Shanghai \\ No.65, Yan An Road (West), Shanghai, 200040, China \\ 中国上海市延安西路65号上海国际贵都大饭店办公楼 405 单元 \\ Phone: +86-21-62489820 \\ Fax: +86-21-62489821
}


(C) 2010 The Author(s). Licensee IntechOpen. This chapter is distributed under the terms of the Creative Commons Attribution-NonCommercialShareAlike-3.0 License, which permits use, distribution and reproduction for non-commercial purposes, provided the original is properly cited and derivative works building on this content are distributed under the same license. 